\title{
特集／低出カレーザーのアトピー性皮膚炎治療への挑戦
}

\author{
低出力レーザーの星状神経節照射治療効果 \\ ーイメージカラーメーターを用いた検討一 \\ 畑 三恵子1)21，石崎 純子2)，秋本眞喜雄 ${ }^{3)}$, 佐々木映子4 \\ 1, 高野医科クリニック \\ 干 125-0062 東京都葛飾区青戸 6-4-23 \\ TEL $\quad 03-3601-2788$ FAX $\quad 03-3601-7727$ \\ 2) 東京女子医科大学附属第二病院皮唐科 \\ 3) 関東学院大学工学総合研究所 \\ 4) 佐々木クリニック
}

\section{Low power laser treatment for atopic dermatitis}

\author{
Mieko HATA, Sumiko ISHIZAKI, Makio AKIMOTO and Eiko SASAKI \\ 1: Takano Medical Clinic 6-4-23, Aoto Katsushika-ku, Tokyo 125-0062 JAPAN \\ 2) Department of Dermatology, Tokyo Women's Medical University Daini Hospital \\ 3) Institute of Science and Technology, Kanto Gakuin University \\ 1) Sasaki Clinic
}

\begin{abstract}
要 旨
重症のアトピー性皮成炎患者 10 例に, 従来の治療に加え, 星状神経節に低出カレーザーを用い たところ，全例で皮疹の改善を認めた，皮疹の重症度，そう痒・不眠のスコアを用いて判定し， さらに我々が開発したImage Colorimeterを用い，皮䖉色の定量を行い客観的に紅斑の改善を数值 で比較検討した。また血液検查による比較も実施した，その結果，いずれの数值も改善され，治 療効果が客観的に示された。

キーワード：アトピー性皮店炎，治療，低出カレーザー，Image Colorimeter，好酸球塩基性蛋白
\end{abstract}

\section{Abstract}

Low power laser treatment on the stellate ganglion was added to the standard treatments for 10 cases of severe atopic dermatitis. Severity of skin lesion, itching and insomnia were scored. And their erythema was measured using Image Colorimeter that we developed. Serum examination for eosinophil cationic protain (ECP) was also performed.

All of those improved after low power laser treatment, which was valuable.

Key words : atopic dermatitis, treatment, low power laser, Image Colorimeter, ECP (Eosinophil cationic protein) 


\section{はじめに}

低出カレーザーが，アトピー性皮膚炎に有効であるこ とを森田ら"が報告し, その後, 庄司が2 星状神経節に 照射し，効果があることを報告している。しかしその客 観的な治療効果判定はなされていなかった。今回，我々 は重症な成人アトピー性皮膚炎患者 10 例の星状神経節 に低出力レーザーを用いたところ有効であったため，ア トピー性皮膚炎に扔ける治療の一手段として用いること ができると考え，その治療効果を客観的に判定すること を目的とした，判定方法は皮疹の重症度およびそう痒・ 不眠のスコアを用いて, 皮疹の改善度を評価し,さらに 主観が含まれないよう血液検查に上る比較に加え， Image Colorimeter を用いて検討した。この装置は，ビ デオカメラと画像解析装置を組み合わせて非接触で皮扂 色測定の定量的解析ができることをすでに報告した3). 特に既存の皮䖉色測定機器は, 測定部位を接触して測定 するために同じ施行者が測定しても一定の数值が得られ ないという問題点があったが，測定施行者や測定方法に 左右されること無く, Image Colorimeter は常に一定の 数值が得られる. 今回, 治療効果判定に用いて非常に有 効であったため，合わせて報告する．

\section{対象および方法}

対 象

Hanifin and Rajka の診断基準 () を満たす成人アトピー 性皮虐炎患者 10 例（男性 4 例，女性 6 例，平均年齢 31.9 葴) で, 従来の治療方法では難治であった症例を選 択した。

\section{照射方法}

波長 $900 \mathrm{~nm}$ の低出力半導体レーザー ( レザック株式 会社: Trinpl D, 最大出力 $10 \mathrm{~W} \cdot$ 平均 $2.4 \mathrm{~W}$, パルスモ ード・パルス幅 $200 \mathrm{~ns}$, 直径 $6 \mathrm{~mm}$ のスポットビーム) を用いた，左右の星状神経節に各 7.5 分間， 1 週間に 1 ～2 回の割合で実施し，治療期間を $6 \sim 8$ 週間でくぎっ た。な扔，外用郕・内服薬の治療方法は変更しないこと を原則とした。

\section{判定方法}

(1) 皮膚の改善度は, 皮疹の症状により $(0)$ 皮疹なし または乾燥肌，（1）紅斑十鱗屑，（2）1＋表皮剥離, 丘疹, 浮腫，（3）１または 2 +苔癞化または膿痂疹 の 4 段階に評価し，9の法則にもとづく皮疹の範囲と の積で 0 300 にスコア化し，重症（150 以上）5名， 中等度 $(50-150) 5$ 名, 軽症 (50 以下) 0 名に分類 した。そう痒と不眠については10段階評価とした。

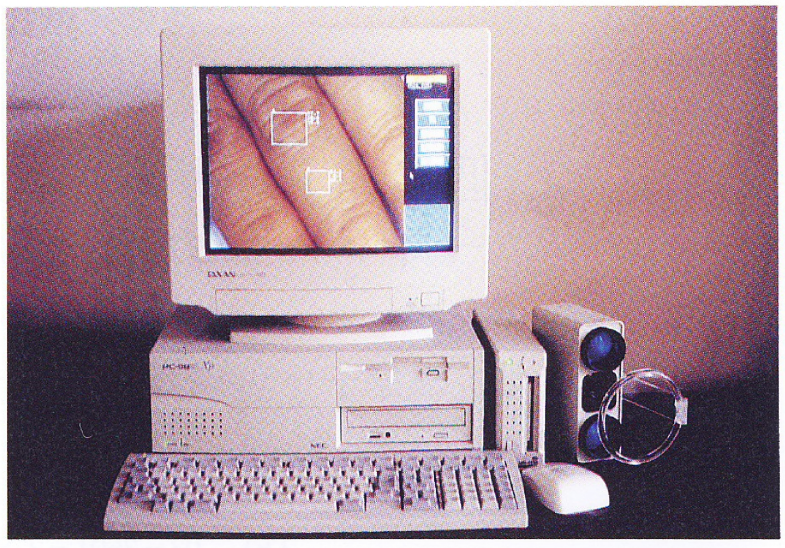

图 1 Image Colorimeter

非接触で病変部分をビデオカメラに記憶させておき, 随時, 測定したい画面および病変部をマウスで選択する ことができる。測定部位の皮膚色測定は瞬時でできる。

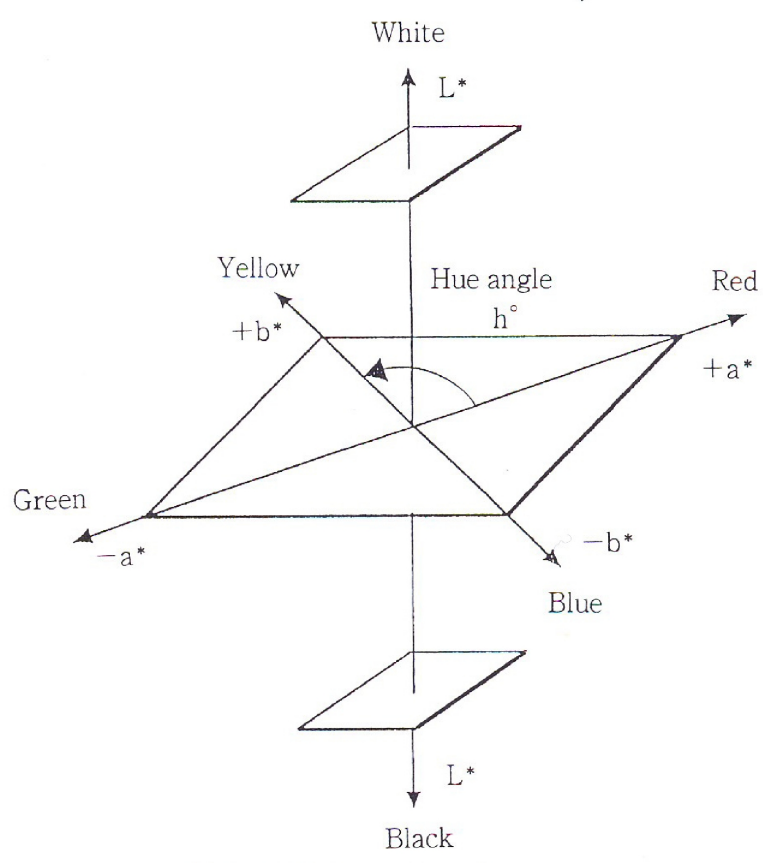

図 2 CIE- L * a *b *color space

一つの色表示は $\mathrm{L} * \mathrm{a} * \mathrm{~b} *$ *の 3 つ值で表現される. 色相角 $\mathrm{h}$ は, $\mathrm{a}$ *軸の赤を 0 度とし, ここから反時計方 向の黄色 90 度に対して移動した角度, つまり赤と黄色 の度合の測定評価を数值で示す。

(2) Image Colorimeter を用いた皮膚色の測定は, 低出 カレーザー施行前後に毎回顔面の同一部位を測定し た。施行者は画像として残したものからいつでも測定 したい部分をマウスにより自由に選択し，瞬時に数字 が表示され定量できる（図１）。色の表現は国際照明 委員会から勧告されている CIE-L* $\mathrm{a} * \mathrm{~b} *$ 系の色彩表 現を利用し, 一つの色表示は $L^{*} a * b * の 3$ つの值で 表現される。今回はアトピー性皮膚炎の炎症性皮膚病 変の治療評価であるため, 色相角 $\mathrm{h}$ を用いて測定した。 
色相角 $\mathrm{h}$ は， $\mathrm{a}$ *軸の赤を 0 度とし，ここから反時計 方向の黄色 90 度に対して移動した角度, つまり赤と 黄色の度合の測定評価を数值で示す（図 2 ).

(3) 血液検査による比較では, 好酸球数, ECP (Eosinophil cationic protein), 好酸球の活性化因子で ある IL-5，ヒト肥満細胞の特異的分泌顆粒であるトリ プターゼについて調べた。 また総 IgE 值，IL-4につい ても調べた。

\section{結 果}

\section{1) 臨床症状のスコアによる改善度}

半導体レーザー治療前のスコアは, 平均 181.7 であっ た。治療期間 6 ～週間後で平均スコアをたしたところ， 全例で症状は軽快し，平均 80.9 に減少していた。そう 瘅のスコアは個人差が大きく臨床症状とは比例しなかっ たが，7.4 から 4.0 に減少し，特に不眠については治療 効果が高く，6例でスコアが1以下になった。平均では

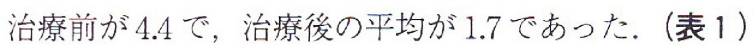

\section{2 ）皮膚色の改善度}

図 3 は, 今回の 10 例について, 治療前・治療後を色 相角 $\mathrm{h}$ で表わした。全例で半導体レーザーの治療前は赤 みが強く, 数值が低かったものが，治療後には赤みが減 少して黄色調が強くなり数值が高くなり健常人の色相角 hの 60〜70に近づいていることがわかる。

症例 1 ：33 歳, 男性 (図 4)。トータルスコア 264の 重症例で，左写真の様に顔面の紅斑が強かったが，半導 体レーザー施行開始 6 週間，11 回めの治療後には全身 の皮疹が軽快し，顔面の紅斑も右写真の様に軽快した。 この様に治療前後で並べて比較すれば治療効果はわかり やすいが，実際には 1 週間に1〜2回の施行ごとに治療 効果を判定しなければならない。そこで Image Colorimeter で毎回測定すると（図５），1回のレーザー 施行前後で数值が上がり赤みが減少し，回数が増加する に従い本人の正常皮膚色の数值に近づいていることがわ かる．特に低出カレーザーは，ステロイド外用剂で難治 な痒疹や苔癬化病変に対し, 効果が認められる(図6). 以上の結果は10例全例でほぼ同様の結果が得られた。

\section{3) 血液検査による比較}

好酸球数（図 7)：数例の重症例では, 皮疹の改善之 好酸球数とは一致しなかったが，10 症例の平均值は治 療前後で減少した。

ECP (Eosinophil cationic protein )（図 8 ）：好酸球の 顆粒蛋白の一つである ECPは，10 例全例で減少した。

トリプターゼ（図９）：測定できた9例中，5例が治
表 1 皮疹の改善度（スコア）

\begin{tabular}{crc}
\hline & 治療前 & 治療後 \\
\hline 皮虐症状 & 181.7 & 80.9 \\
瘤痒 & 7.4 & 4.0 \\
不眠 & 4.4 & 1.7 \\
\hline
\end{tabular}

Erythema

(Yellower) Hue angle $\left(h^{\circ}\right)$

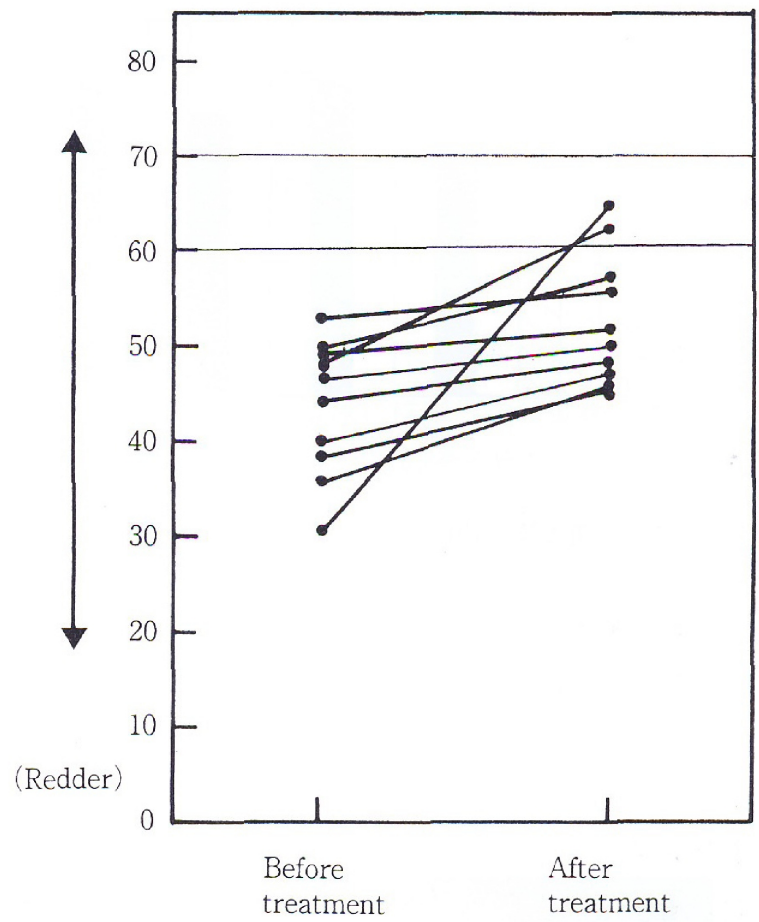

図 3 低出カレーザー治療前後の 10 例の皮膚色測定値 (Image Colorimeter による測定)

皮膚色を赤と黄色の揢合だけで測定したもので，０度 にちかいほど赤く, 紅斑が減少してくると赤みが減少し， 90 度の黄色に近づく. 黄色人種では黄色調が強くなり健 常人の色相角 $\mathrm{h}$ は $60 \sim 70$ 度に近づく.10 例全例で治療 後は紅斑が減少し，数字が上昇して健常人皮虔色に近づ いていることがわかる。

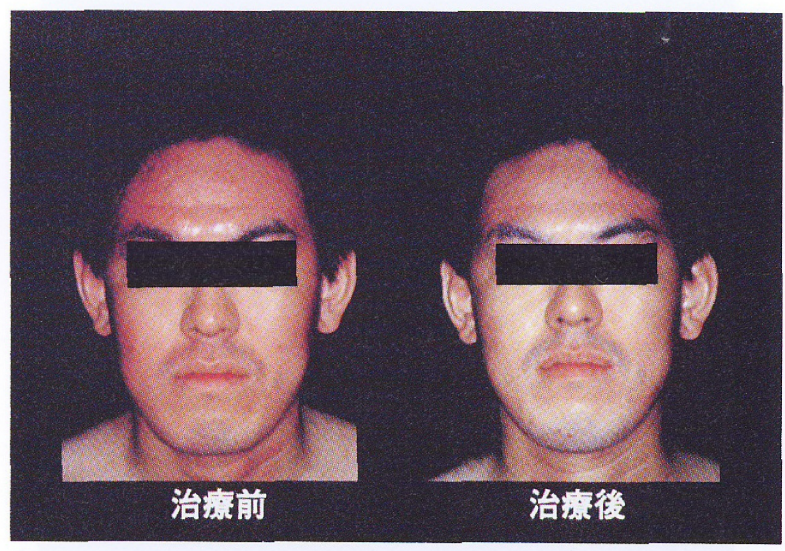

図 433 歳, 男性.

治療前後で, 顔面の紅斑が減少している。低出力レー ザー施行開始 6 週間, 11 回目 
Erythema

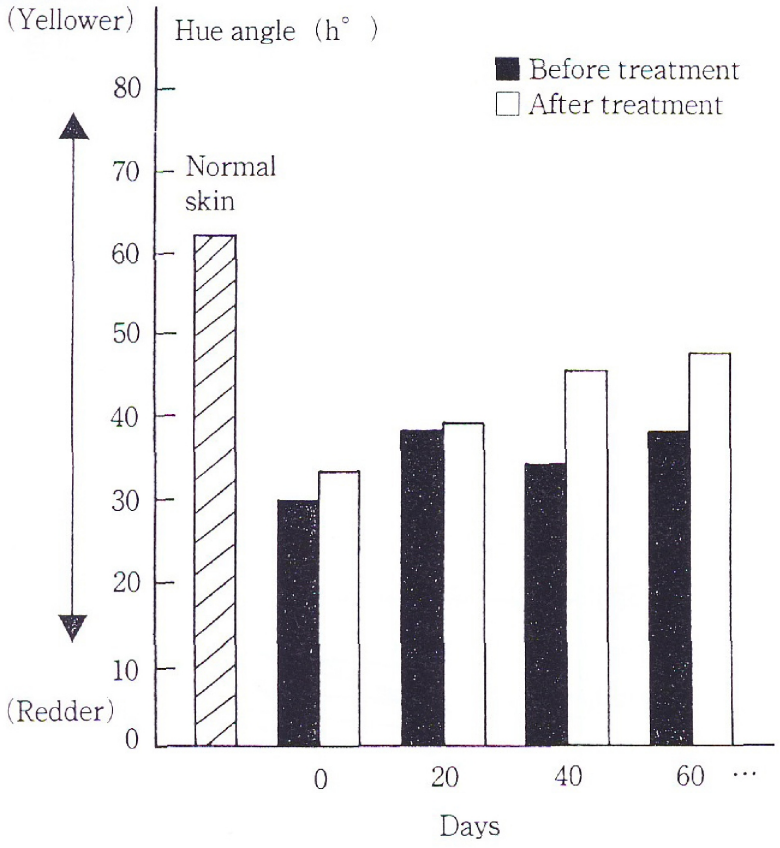

図 5 図 4 同一症例. Image Colorimeter 測定值.

1 回のレーザー施行前後で数值が上がり赤みが減少し, 回数が増加するに従い本人の正常皮膚色の数值に近づいて いることがわかる。

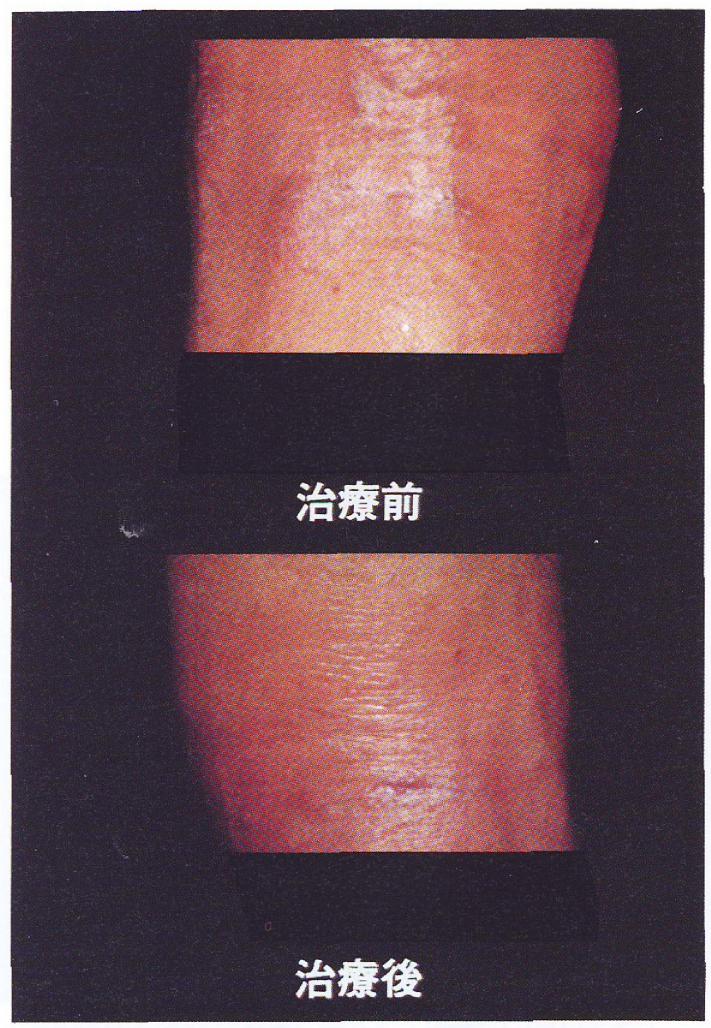

図 6 低出カレーザーは, ステロイド外用剤で難治な棒 㾉や苔㿏化病変に対し，特に効果が認められる.

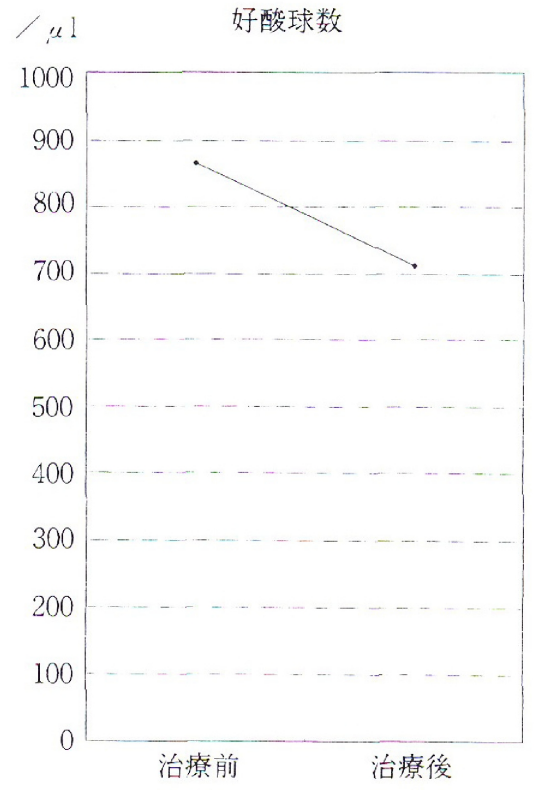

図 7 治療前後の好酸球数 ( 10 例平均値)

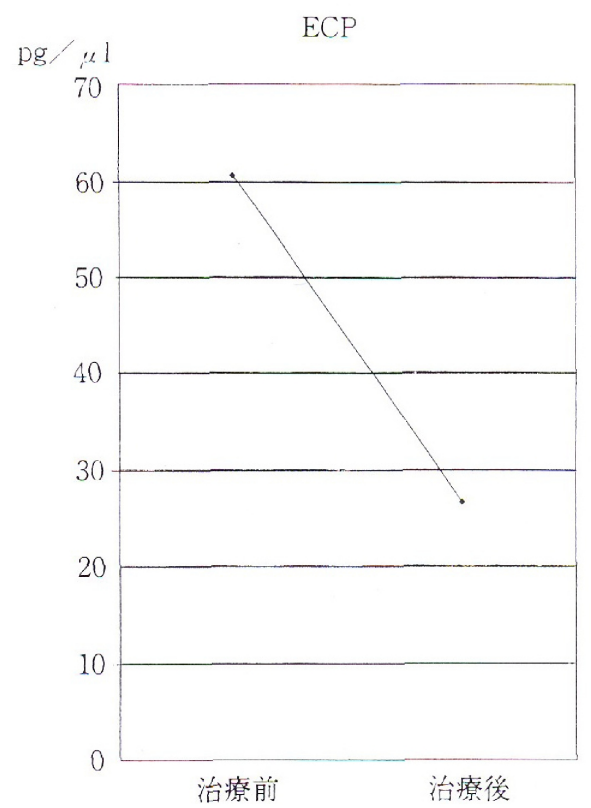

図 8 治療前後の ECP 值( 10 例平均值)

療前後でごく軽度の減少を認めたが，３例では逆に軽度 上昇，1例は変化を認めなかった。トリプターゼが軽度 上昇した例でも臨床症状は軽快していた。

なお, IL-5 は測定值が $5.0 \mathrm{pg} / \mathrm{ml}$ 以下の低值例が多く, 治療による比較はできなかった。総 $\mathrm{IgE}$ 值, IL-4 も改善 度と無関係だった。

\section{考案}

医療分野で使用されている低出力レーザーは, 半導体 レーザー, He-Ne レーザー, YAGレーザーが主流で, 中でも半導体レーザーが最も多く使用されている。半導 


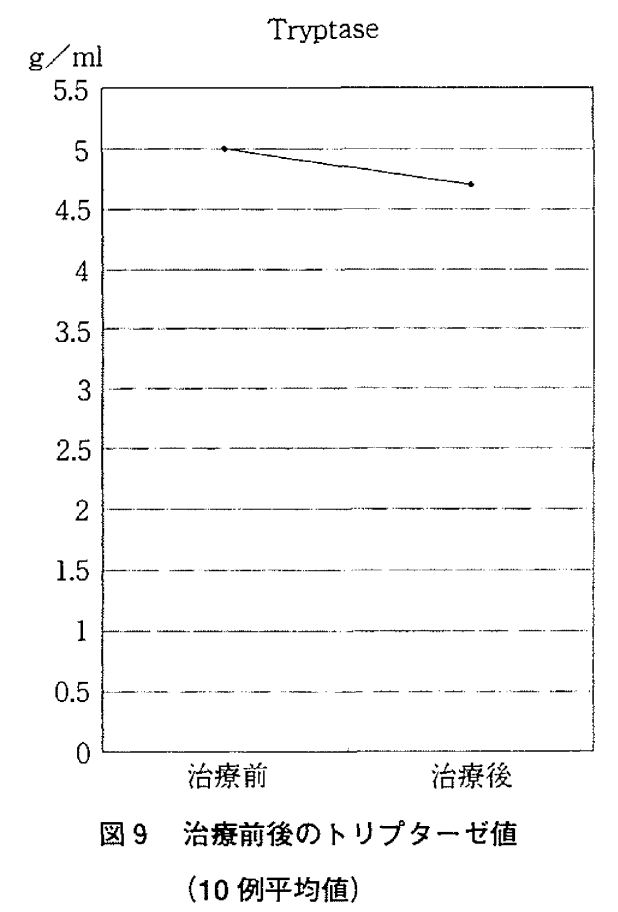

体レーザーは赤外線領域の長波長の光である（今回用い た $900 \mathrm{~nm}$ は近赤外線光). 低出力レーザーは光生物学的 活性化反応を持つといわれ，生体組織を破壇しないとい う特徴がある。

皮店科領域では带状疮疹の疼痛緩和に用いられ，その 効果は知られている5.6!.アトピー性皮㖇炎には，森田 ら”や庄司がッ効果があることを報告しているが，客観 的な効果については明確でなかった，我々も，成人アト ピー性皮硐炎難治例の星状神経節に用いたところ非常に 有効であったため，客観的治療判定を試みた，臨床的に 皮疹の重症度, そう痒・不眠のスコアを用いて低出力半 導体レーザー治療の前後で比較した結果, 全例が改善さ れ，効果が示された．しかしこれらのスコアも主観が入 ることは免れない。そこで Image Colorimeter を用いた 皮虔色の測定を実施し，その効果を数值で比較した。今 回はアトピー線皮膚炎の炎症性皮䖉病変の治療評価であ るため，色相角 hを用いて測定した。実際に，アトピー 性皮清炎のような炎症性皮难病変についての治療評価で は，皮覤科医は無意識のうちに，その病変の赤みの強さ に着目して治療が有効であるかどうかを評価している。 たとえば，赤みが消失し色素沈着が残ったとしても，赤 みを主体に考え，皮疹が軽快していると判断する。色相 角 $\mathrm{h}$ では， $\mathrm{a}$ *軸の赤を 0 度とし，ここから反時計方向 の黄色 90 度に対して移動した角度で色の数值を示す。 赤みが強いほど 0 度に近づき，赤みが減少すると黄色人 種では黄色調が強くなり健常人の色相角 hの 60７0 度
に近づく．今回，10例全例がレーザー施行前後で紅斑 が減少し，正常皮膚色に近づいていることが確認できた。 色相角 $\mathrm{h}$ は赤と黄色の度合の測定評価ができ，黄色人種 の炎症性皮痛病変評価に適していた。

また血液検査による比較では，ECP の血中濃度がア トピー性皮䖉炎の重症度の良い指標になるといわれてい るマー9?. 全例で ECP 值が減少した結果より, 半導体レ ーザーによる効果が有効であったことを示唆するもので ある．なお低出力レーザー治療後にそう痒が軽減するこ とから，肥満細胞の脱顆粒抑制作用が推定され，ヒト肥 满細胞の特異的分泌顆粒であるトリプターゼについて測 定したそその結果，10 例の平均值では軽度減少したが， 臨床症状とは相関しなかった。

その他，全例で半導体レーザー試行前後にサーモグラ フィを行ったところ施行後には明らかに全身の体温が上 昇していた：そして患者全員のそう痒スコアが減少し， 一部の患者は，施行中に眠気を感じ，夜間熟睡できるよ うになった。低出力レーザーの使用は，局所麻酔剂によ る神経ブロックに代わりペインクリニックで頻用され， 交感神経が抑制されると推定されているが，痛みだけで なく痒みにも有効であると考える。

ところで，低出カレーザーの作用機序については不明 な点が多い。森田ら"はアトピー性皮成炎の皮疹部に照 射L，表皮内 HLA-DR 陽性樹枝状細胞，及び ICAM-1 陽性細胞が減少していることを報告した。また感作惹起 誘導した耳介腫脹は，レーザー照射側が明らかに優位に 抑制され，免疫㧕制作用があると述べている，その他， 低出力レーザーの細胞に対する様々な報告があり，守本 ら以は低出カレーザーの生物学的効果の主体は細胞增殖 作用であり，最初の光受容体はミトコンドリア内膜上の 呼吸鎖構成要素であるとしている，低出力レーザーの作 用機序についてはまだ解明されていないが，今後も臨床 治療に十分利用できる方法の一つであると考える。

\section{結 論}

重症のアトピー性皮凰炎患者 10 例に，従来の治療に 加え星状神経節に低出力レーザーを用いたところ，臨床 評価, Image Colorimeter を用いた皮膚色の定量，好酸 球数，ECP 測定とも数值が改善され，治療効果が客観 的に示された。

\section{文 献}

1）森田秀樹，喜多野征夫，相模成一郎：アトピ一性皮成炎 に対する治療の現況，兵庫県医師会医学雑誌，35： 
$116-119,1993$

2）生司昭伸：8。追加発言アトピー性皮用炎の治療におけ る低出カレーザーの応用，日本皮成科学会第 63 回東京 支部学術大会シンポジウム】「アトピー性皮成炎にかか わる神経要因」P 92,2000

3 ）畑三恵子, 秋本眞喜雄, 川名誠司ほ加：Image Colorimeter による皮感色の定量一第 1 報, 日皮会誌, $109: 2237-2241,1999$

4) Hanifin JM, Rajka G : Diagnostic features of atopic dermatitis, Acta Derm Venereol (Suppl.) $92: 44-47$, 1980

5 ）山田裕道，小川秀與：低反応レベルレーザーを用いた帯 状疮疹後神経痛の治療, 臨床皮席科, 49:283-285, 1995

6）込山悦子，松葉よう子，岩本真一郎ほか：帯状疮疹後神 経痛に対する低反応レベルレーザー治療（第 3 報）自験 例 100 例による評俩，臨床皮虑科，54：1045-1049， 2000

7 ）森田秀樹，堀 美佳，木原貴子ほか：アトピー性皮㡱炎 における血清 ECP の検討, 皮虔科紀要, 86：149-151, 1991

8）森田詠伸，高路 修，原田佳代ほか：成人型アトピー性 皮有炎患者における血清 Eosinophil Cationic Protein (ECP) の検討，西日皮店，55:476-479，1993

9 ) 大砂博之, 竹川 清, 大沼すみほか：アトピー性皮掐炎 の全般的重症度, 短期病势, 長期病势の検査值による評 価, 皮用, 38:93-99，1996

10）守本祐司, 荒井恒憲: 低出カレーザー生体作用の生物学 的立場からの考察，日レ医誌，18：9-17，1997 